\title{
Pengaruh Penambahan Pengawet Alami terhadap Kualitas Gula Aren (Arenga pinnata Merr.) yang Dihasilkan
}

\section{The Effect Of Additions Natural Preservatives To The Quality Of Palm Sugar (Arenga pinnata Merr.) Will Be Result.}

Nurhayati Tanra, Program Studi Pendidikan Teknologi Pertanian Fakultas Teknik, Universitas Negeri Makassar. Email: ntanra@gmail.com

Husain Syam, Program Studi Pendidikan Teknologi Pertanian Fakultas Teknik, Universitas Negeri Makassar. Email: husain6677@yahoo.co.id

Andi Sukainah, Program Studi Pendidikan Teknologi Pertanian Fakultas Teknik, Universitas Negeri Makassar. Email: andisukainah@yahoo.com

\begin{abstract}
Abstrak
Tujuan dari penelitian ini adalah untuk mengetahui pengaruh penambahan pengawet alami terhadap kualitas gula aren (Arenga pinnata Merr.) yang dihasilkan. Metode penelitian ini Rancangan Acak Lengkap (RAL) dengan dua faktor dan data yang diperoleh akan dianalisis dengan analisis sidik ragam dan uji lanjut Duncan Multiple Rate (DMRT) dengan 6 perlakuan dan 1 kontrol yang dilakukan sebanyak 3 kali ulangan didapatkan 21 unit percobaan. Perlakuan dalam penelitian ini adalah Faktor pertama yaitu konsentrasi penambahan pengawet alami dengan konsentrasi $0 \%, 8 \% 10 \%$ dan $12 \%$ dan faktor kedua yaitu jenis pengawet alami terdiri dari Ddaun jambu biji dan batang kayu nangka, dengan parameter pengamatan; $\mathrm{pH}$, Sachharomyces cerevisiae, Acetobacter aceti, kadar gula reduksi dan kadar air. Hasil penelitian menunjukkan bahwa konsentrasi penamabahan $12 \%$ dengan jenis pengawet alami batang kayu nangka merupakan perlakuan terbaik pada nilai $\mathrm{pH}$, jumlah Saccharomyces cerevisiae, Acetobacter aceti, jumlah kadar gula reduksi dan jumlah kadar air.
\end{abstract}

Kata Kunci: Penambahan, Pengawet Alami, dan Gula Aren

\section{Abstract}

The purpose of this reserch was to determine the effect of additions natural preservatives to the quality of palm sugar (Arenga pinnata Merr.) that will be result. This research uses the Completely Randomized Design (CRD) method with two factors and the data obtained will be analyzed by analysis of variance and Duncan Multiple Rate (DMRT) further test with 6 treatments and 1 control performed in 3 replications with 21 unit trial. Treatment in this research is; The first factor is the concentration of the addition of natural preservatives with a concentration of $0 \%, 8 \% 10 \%$ and $12 \%$ and the second factor, namely a type of natural preservative consisting of guava leaves and jackfruit wood stems. with observational parameters; pH, Sachharomyces cerevisiae, Acetobacter aceti, sugar reduction content and water content. The results showed that the concentration of addition of $12 \%$ with the type of natural preservative of jackfruit wood was the best treatment at the $\mathrm{pH}$ value, the amount of Saccharomyces cerevisiae, Acetobacter aceti, the amount of sugar reduction content and the amount of water content.

Keywords: Additions, Natural Preservatives, and Palm Sugar 


\section{Latar Belakang}

Gula sebagai sukrosa diperoleh dari nira tebu, bit gula atau aren (Ernasari et al, 2018). Gula adalah salah satu kebutuhan pokok masyarakat, dan merupakan komoditi yang dikonsumsi oleh seluruh lapisan masyarakat. Kebutuhan konsumsi gula meningkat dari Tahun ke Tahun. Pada Tahun 2017 Kebutuhan konsumsi gula mencapai 5,7 juta ton. Salah satu jenis gula yang dibutuhkan oleh masyarakat umum adalah gula merah. Pada tahun 2017, konsumsi rata- rata gula merah per kapita serminggu mencapai 0,129 ons (Badan Pusat Statistik, 2018). Bahan baku pembuatan gula merah salah satunya yaitu nira aren. Nira aren dengan kualitas yang baik akan menghasilkan gula merah dengan kualitas yang baik pula.

Kurangnya penanganan pada tahap penyadapan nira dapat menyebabkan fermentasi hal ini disebabkan oleh adanya aktivitas enzim invertase karena adanya mikroba yang mengkontaminasi nira diantaranya adalah Saccharomyces cerevisiae yang membantu hidrolisis sukrosa sehingga menghasilkan fruktosa dan glukosa (Marsigit. 2005) fruktosa memiliki sifat higroskopis. Selain itu, kualitas nira yang terfermentasi akan menghasilkan nira aren yang kurang baik untuk diolah menjadi gula aren, di dalam nira aren terdapat mikroorganisme indigenus. Mikroba indigenus adalah kelompok mikroba yag terlibat dan ditemukan selama proses feremntasi ( Sukainah et al, 2017).

Mikroorganisme yang paling dominan terdapat pada nira Aren adalah khamir, khamir yang terdapat dalam jumlah besar pada nira adalah Sacharomyces sp, sedangkan bakteri yang ditemukan dari genus Acetobacter, Sarcina, Leuconostoc, Brevibacterium, Serratia dan Pediococcus (Muchtadi. 2010), Jenis kamir dari genus Saccharomyces cereviceae dikenal sebagi mikroorganisme yang dapat menfermentasi glukosa menjadi etanol. Bakteri dari genus Acetobacter bisa mengoksidasi etanol menjadi asam asetat, rasa asam pada nira ini membuatnya tidak baik untuk diolah menjadi gula aren, oleh karena itu dibutuhkan senyawa yang dapat menghambat fermentasi oleh Saccharomyces dan Acetobacter. Bahan alami yang mengandung senyawa yang dapat menghambat pertumbuhan mikroba, yaitu daun jambu biji dan kayu nangka.

Daun jambu biji (Psidii folium) berasal dari tanaman Psidii guajava L. (fam. Mvrtaceae). Daun jambu biji mengandung senyawa aktif seperti tannin, triterpenoid, saponin, eugenol, dan flavonoid. Senyawa dalam dan jambu biji yang berupa flavonoid, tannin dan terpenoid mempunyai efek antibakteri dengan merusak struktur membrannya (Soritua et al. 2015). Senyawa yang terkandung di dalam daun jambu biji tersebut dapat menghambat fermentasi pada nira aren karena dapat menghambat pertumbuhan mikroba bahkan dapat mematikan mikroba.

Selain daun jambu biji kayu nangka juga memiliki banyak kandungan antimikroba, sifat antimikroba tersebut dapat memperpanjang umur simpan pada nira. Kandungan kimia kayu nangka tersebut antara lain alkaloid, flavonoid, tannin yang dapat mengawetkan nira karena memiliki sifat antimikroba. Sesuai dengan pernyataan Ersam (2001) yang menyatakan bahwa kandungan kimia kayu nangka antara lain morin, sianomaklurin 
(zat samak), flavon dan tannin yang mempunyai sifat mematikan bakteri atau daya bakteriostatik. Namun belum diketahui konsentasi yang optimal sebagai pengawet alami nira dan belum dilanjutkan pengolahan menjadi gula aren.

Oleh karena itu, dalam penelitian ini akan ditambahkan pengawet alami berupa daun jambu biji dan kayu nangka yang berfungsi sebagai antimikroba sehingga dengan adanya penambahan daun jambu biji dan kayu nangka dapat mencegah fermentasi yang terjadi pada nira sehingga

\section{Bahan dan Metode}

\section{Jenis Penelitian}

Jenis Penelitian ini termasuk penelitian eksperimen dengan pendekatan kuantitatif. Pendekatan penelitian merupakan langkah- langkah dalam melaksanakan penelitian, dalam penelitian ini akan diteliti pengaruh variabel tertentu dalam kondisi yang dikontrol. Rancangan percobaan yang digunakan dalam penelitian ini adalah Rancangan Acak Lengkap (RAL) Faktorial dengan dengan dua faktor, terdiri dari 6 perlakuan dan 1 kontrol dengan 3 kali ulangan, sehingga didapatkan 21 perlakuan.

\section{Tempat dan Waktu Penelitian}

Pembuatan sample dilakukan di Desa Tetewatu Kec. Lilirilau Kab. Soppeng, pengujian Saccharomyces cerevisiae dan Acetobacter aceti dilakukan di Laboratorium Biologi, Fakultas Matematika dan Ilmu Pengetahuan alam Universitas Negeri Makassar dan pengujian gula reduksi dan kadar air dilakukan di Laboratorium KimiaMakanan Ternak Fakultas Pertanian Universitas Hasanuddin. Penelitian ini mulai gula merah yang dihasilkan memiliki kualitas yang bagus.

\section{Tujuan Penelitian}

Penelitian ini bertujuan untuk mengetahui bagaimana pengaruh konsentrasi dan jenis pengawet alami batang kayu nangka dan daun jambu biji terhadap fermentasi nira aren dan untuk mengetahui bagaimana pengaruh konsentrasi dan jenis pengawet alami kayu nangka dan daun jambu biji pada nira terhadap kualitas gula aren yang dihasilkan.

dilaksanakan pada bulan OktoberDesember 2018.

\section{Alat dan Bahan}

Alat-alat yang digunakan dalam pengolahan nira aren ini meliputi : Gelas Ukur, timbangan, botol sample, plastik cetik, kompor, wadah penampung nira aren, cetakan gula, wajan, mangkok, sedangkan peralatan yang akan digunkan selama penelitian antara lain $\mathrm{pH}$ meter, timbangan analitik, autoklaf, lemari asam, lemari pembiakan, lampu bunsen, cawan petri, gelas ukur, tabung reaksi, botol pengencer, timbangan analitik, pipet mikro, botol semprot, dan colony counter. Bahan - bahan yang digunakan dalam proses pengolahan gula aren adalah: Nira aren, daun jambu biji, dan batang nangka, sedangkan bahan yang digunakan dalam penelitian adalah air nira, media Peptone Extract- Glucose (PYG), media NA, media TSIA, etanol $90 \%$, akuades 1 liter, kristal violet, alkohol aseton, kapas, kertas oksidase, kertas label dan alumunium foil. 


\section{Prosedur penelitian}

\section{Pembuatan pengawet alami}

Perlakuan pembuatan pengawet alami: diambil bagian yang paling dalam dari bahan pengawet alami yaitu kayu nangka, kemudian dipotong-potong sehingga ukurannya menjadi kecil dan ditimbang sebanyak 100 g. Direbus dengan air sebayak $200 \mathrm{ml}$ selama 30 menit sampai mendidih, setelah air mendidih dimasukkan 100 g kayu nangka ke dalam air mendidih tersebut dan diaduk sampai merata. Dibiarkan sampai pengawet alami dingin (pada suhu kamar). dan untuk daun jambu biji diambil dari daun muda kemudian dipotong-potong sehingga

\section{Pembuatan gula aren}

Gula aren dibuat dari nira yang telah ditambahkan pengawet alami. Nira hasil penyadapan dimasak dengan kompor sampai mencapai end point suhu $115^{\circ} \mathrm{C}$. Pemanasan disertai pengadukan dilanjutkan sampai membentuk solidifikasi, kemduain dicetak dan menghasilkan gula aren cetak.

\section{Teknik Pengumpulan dan Analisis data}

Teknik pengumpulan data yang dilakukan dalm penelitian ini menggunakan pengamatan ini menggunakan pengamatan dan pencatatan ukurannya menjadi kecil dan ditimbang sebanyak 100 g. Direbus dengan air sebayak $200 \mathrm{ml} \mathrm{s}$ selama 30 menit sampai mendidih, setelah air mendidih dimasukkan $100 \mathrm{~g}$ daun jambu biji dimasukkan dalam air mendidih tersebut dan diaduk sampai merata. Dibiarkan sampai pengawet alami dingin (pada suhu kamar)

\section{Penambahan pengawet alami pada nira aren}

Pengawet alami dilakukan pada nira aren, konsentrasi pengawet alami yang ditambahkan yaitu; $80 \mathrm{ml}, 100 \mathrm{ml}$ dan 100 $\mathrm{ml}$ nira hasil penyadapan dicampur secara homogen dan dituang ke dalam wadah.

secara sistematis terhadap subjek penelitian.

Teknik analisis data yang digunakan meliputi uji persyaratan analisis yang terdiri dari uji normalitas dan homogenitas. Apabila data yang diperoleh bersifat normal Apabila data yang diperoleh bersifat normal dan homogen maka akan dilanjutkan dengan uji statistik sidik ragam anova. Jika $\mathrm{H} 1$ diterima maka akan dilakukan uji lanjut dengan menggunakan uji Duncan pada taraf signifikan $\alpha=0,05$. Data diolah menggunakan sppss versi

\section{Hasil dan Pembahasan}

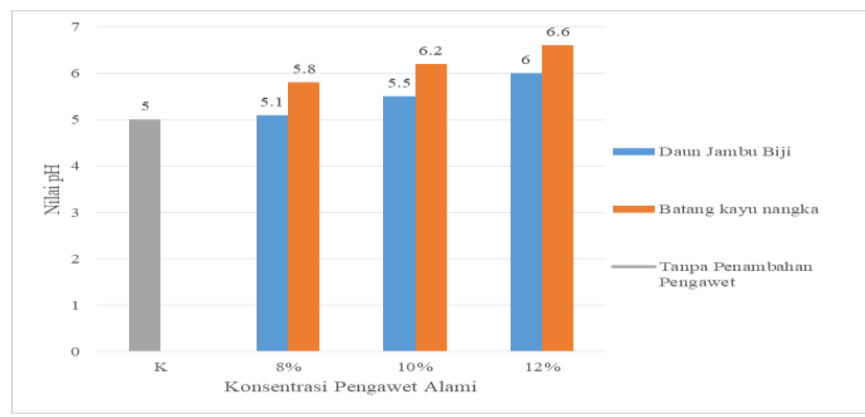

Gambar 1. Nilai pH 
Berdasarkan hasil pengamatan tersebut, hasil pengujian nilai $\mathrm{pH}$ menunjukkan bahwa semakin tinggi konsentrasi maka semakin tinggi nilai $\mathrm{pH}$ yang dihasilkan, dan untuk jenis pengawet alami menunjukkan bahwa perlakuan jenis pengawet alami batang kayu nangka memiliki nilai $\mathrm{pH}$ yang lebih tinggi dibandingkan dengan nilai $\mathrm{pH}$ pada daun jambu biji.

Nilai $\mathrm{pH}$ adalah simbol untuk derajat keasaman atau alkalinitas suatu larutan, nilai $\mathrm{pH}$ sangat penting untuk pertumbuhan mikroorganisme, karena kinerja enzim sangat dipengaruhi oleh $\mathrm{pH}$ (Sukainah, A et al, 2018).

Hasil analisis sidik ragam menunjukkan bahwa nilai $\mathrm{F}$ hitung $>\mathrm{F}$ tabel (Lampiran 3.1), pada konsentrasi penambahan pengawet alami dan jenis pengawet alami berpengaruh sangat nyata terhadap tingkat $\mathrm{pH}$ pada nira, sehingga dilanjutkan uji duncan. Data pengujian duncan menunjukkan bahwa perlakuan terbaik untuk parameter nilai $\mathrm{pH}$ pada faktor konsentrasi yaitu pada konsentrasi $12 \%$, hal ini disebabkan karena semakin tinggi konsentrasi maka semakin tinggi kandungan antimikroba sehingga fermentasi dapat dicegah karena adanya penghambatan pada pertumbuhan mikroba hal ini sesuai dengan pendapat Sirotua, et al. (2015) yang mengatakan bahwa semakin tinggi konsentrasi bahan pengawet alami maka $\mathrm{pH}$ nira semakin tinggi karena kandungan zat yang dapat menghambat pertumbuhan mikroba sehingga memberi pengaruh terhadap $\mathrm{pH}$. Sumanti, et al (2004) bahwa alkaloid, flavanoid, dan triterpenoid yang bersifat sebagai anti mikroba dan hal tersebut dapat menghambat laju penurunan $\mathrm{pH}$.
Karena semakin banyak mikroba maka semakin rendah pula nila $\mathrm{pH}$, hal ini sesuai dengan pernyataan Sukainah et al (2018) bahwa semakin banyak jumlah mikroganisme yang akan tumbuh menghasilkan asam, sehingga nilai $\mathrm{pH}$ akan menurun dengan meningkatkan konsentrasi asam terlarut.

Pengawet alami perlakuan batang kayu nangka lebih baik dibandingkan dengan perlakuan daun jambu biji, hal ini disebabkan karena kandungan antimikroba batang kayu nangka lebih banyak dibandingkan dengan antimikroba yang terdapat pada dau jambu bij, kandungan antimikroba kayu nagka yakni flavanoid, streoid, tannin, saponin, sianomaklurin, flavon, morin dan alkaloid (Lubis, et al. 2013) sedangkan kandungan antimikroba dau jambu biji yakni Flavanoid, steroid, tannin, saponin dan euganol (Indriani. 2006).

\section{Saccharomyces cerevisiae}

Berdasarkan hasil penelitian tersebut, jumlah khamir Saccharomyces cerevisiae berdasarkan konsentrasi pengawet alami, yaitu semakin tinggi konsentrasi maka jumlah khamir Saccharomyces cerevisia semakin sedikit begitupun sebaliknya, dan untuk jenis pengawet alami batang kayu nangka lebih menghambat pertumbuhan khamir karena jumlah khamir Saccharomyces cerevisia yang lebih rendah dibandingkan dengan penambahan pengawet alami daun jambu biji. 


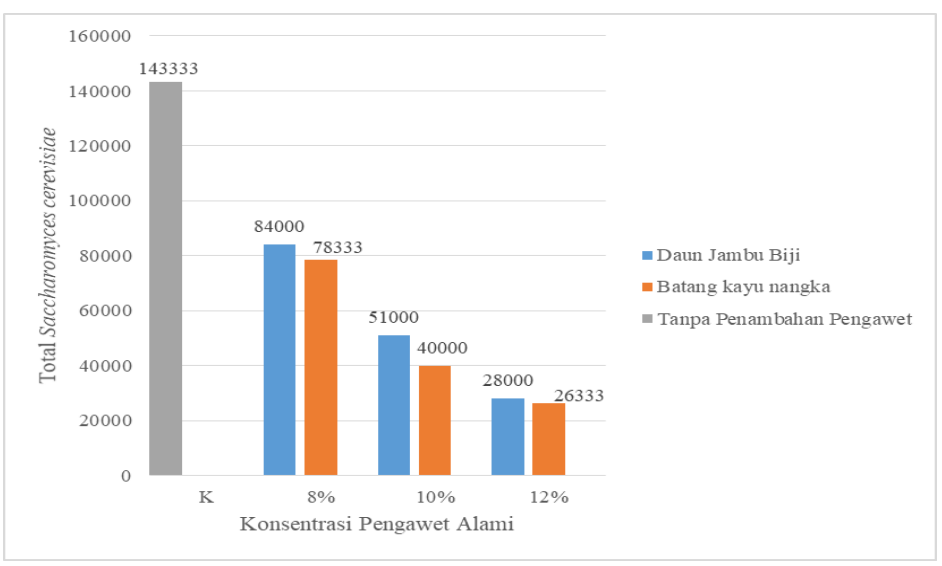

Gambar 2. Total Saccharomyces cerevisiae

Saccharomyces cerevisiae merupakan organisme penghasil amilase yng cukup berpotensi, selain bakteri dan kapang. Enzim amilase diproduksi diluar oleh beberapa jenis yeast, khamir Saccharomyces cerevisiae enzim amilase dapat menghidrolisa ikatan $\alpha$ pada amilopektin dan merubahnya menjadi etanol (Erna. 2013).

Hasil analisis sidik ragam menunjukkan bahwa nilai $\mathrm{F}$ hitung $>\mathrm{F}$ tabel pada konsentrasi penambahan pengawet alami berpengaruh sangat nyata terhadap jumlah khamir Saccharomyces cerevisiae, sehingga dilanjutkan uji duncan, Data hasil pengujian duncan menunjukkan bahwa perlakuan terbaik pada konsentrasi pengawet alami sebesar $12 \%$, hasil menunjukkan bahwa jumlah saccharomyces terendah yaitu $12 \%$ hal ini disebabkan karena semakin tinggi konsentrasi maka semakin banyak pula kandungan antimikroba sehingga dapat menghambat pertumbuhan mikroba hal ini sesuai dengan pernyataan Afifi \& Erlin (2017) bahwa konsentrasi anti mikroba mempengaruhi pertumbuhan mikroba, dimana semakin besar konsentrasi maka menyebabkan jumlah kematian yang lebih besar terhadap mikroba.
Jenis pengawet alami batang kayu nangka lebih baik daripada pengawet daun jambu biji, hasil menunjukkan jumlah Saccharomyces cerevisiae terendah hal ini terjadi karena batang kayu nangka memiliki kandungan antimikroba yaitu alkaloid, flavanoid, tannin, steroid, sianomaklurin, flavon dan saponin sedangkan jenis antimikroba yang terdapat pada daun jambu biji ialah steroid flavanoid, euganol dan saponin, hal ini sesuai dengan pernyataan Setya et al. (2011) mengatakan bahwa kandungan kimia kayu nangka antara lain morin, sanomaklurin, flavon selain itu dibagian kulia kayu nangka juga memiliki senyawa flavanoid yang baru, yakni morusin, artokaprin, artonin E, sikloatrobilosanton, dan artonol B sedangkan untuk daun jambu biji mengandung senyawa aktiv seperti tannin, titerpenoid, saponin, euganol dan flavanoid (Sirotua, et al. 2015).

Golongan senyawa alkaloid, fenolat, tannin, flavanoid, saponin, dan terpenoid memiliki aktivitas antijamur yang tinggi, mekanisme penghambatan khamir oleh antijamur yakni dengan menghambat sintesis ergosterol yang mengakibatkan permeabilitas membran sel pada khamir 
meningkat, selain itu antijamur ini juga menyebabkan gangguan sintesis asam nukleat pada sel jamur yang akan menimbulkan kerusakan pada sel jamur tersebut (Candra, 2009).

\section{Acetobacter aceti}

Penambahan daun jambu biji dan batang kayu nangka menunjukkan bahwa semakin tinggi konsentrasi pengawet alami maka semakin sedikit jumlah bakteri Acetobacter aceti pada nira, dan untuk jenis pengawet alami batang kayu nangka jumlah bakteri yang tumbuh lebih rendah dibandingkan dengan jumlah bakteri yang tumbuh pada penambahan daun jambu biji.

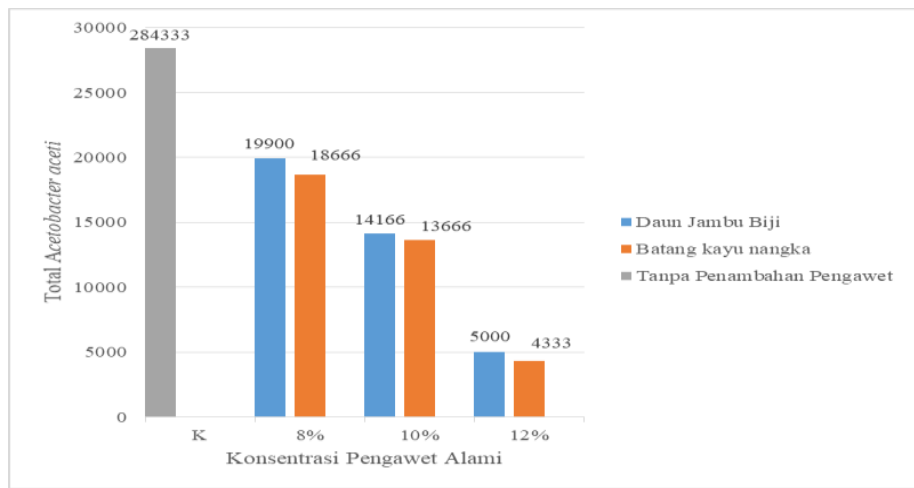

Gambar 3. Total Acetobacter aceti

Hasil analisis sidik ragam menunjukkan bahwa nilai $\mathrm{F}$ hitung $>\mathrm{F}$ tabel pada konsentrasi pengawet alami berpengaruh nayat terhadap jumlah bakteri Acetobacter aceti, sehingga dilanjutkan uji duncan, Data Hasil uji duncan menunjukkan bahwa perlakuan terbaik pada konsntrasi $12 \%$ hal ini disebabkan karena semakin tingginya konsentrasi menandakan semakin tinggi pula daya bakteriostatik sehingga semakin tinggi konsetrasi bakteri pun semakin sedikit. Pada konsentrasi rendah zat antibakteri dapat bersifat bakteriostatik yakni bekerja menghambat pertumbuhan bakteri sedangkan pada konsentrasi tinggi zat antibakteri dapat bersifat bakterisidal yakni bekerja mematikan bakteri (Chomnawang et al., 2005).

Jenis pengawet alami yakni pada jenis pengawet alami batang kayu nangka lebih baik dibandingkan dengan pengawet daun jambu biji, hal ini terjadi karena tingginya kandungan flavanoid pada kayu nangka dibandingkan dengan daun jambu biji dilihat dari warna merah pada air rebusan batang kayu nangka yang lebih pekat, hal ini sesuai dengan pernyataan Widowati (2017) bahwa kandungan flavanoid terbesar terdapat pada kayu nangka.

Menurut Pratiwi, et al (2014) bahwa flavanoid menghambat pembentukan bakteri dengan 3 cara yaitu mekanisme pembentukan bakteri dengan menghambat sintesis asam nukleat, menghambat sintesis dinding sel, dan merusak membran sel bakteri, steroid menyebabkan integritas membran sel menurun sehingga menyebabkan membran sel berubah akibatnya sel rapuh dan lisis, tannin menyebabkan kerusakan pada bakteri karena berekasi dengan membran sel sehingga menyebakan kerusakan materi 
genetik, saponin pada membran sel membentuk ikatan polimer yang kuat mengakibatkan rusaknya porin yang menyebabkan rusaknya sel bakteri sehingga pertumbuhan bakteri terhambat atau mati (Rahmawati et al, 2009), dan untuk alkaloid menghambat pertumbuhan bakteri dengan cara menghambat enzim yang berperan dalam proses replikasi DNA sehingga bekteri tidak dapat melakukan pembelahan menyebabkan pertumbuhan bakteri terhambat seperti pada Gambar 4.6 (Ernawati \& Kumalasari. 2015). Menurut Maryati \& Karmila (2008) bahwa euganol merupakan senyawa hidrofobik yang mudah melewati dan merusak dinding sel bakteri gram negatif yang memiliki konsentrasi yang tinggi. Mekanisme antibakteri tanin dengan cara merusak dinding sel bakteri yaitu dengan memanfaatkan perbedaan kepolaran antara lipid penyusun sel bakteri dengan gugus alkohol pada senyawa tanin (Jayadi et al, 2018).

\section{Konsentrasi dan Jenis Pengawet Alami terhadap Kualitas Gula Aren Kadar Air}

Pada Gambar 4 terlihat bahwa semakin tinggi konsentrasi pengawet alami maka semakin rendah kadar air yang dihasilkan, dan untuk jenis pengawet alami penambahan batang kayu nangka menghasilkan kadar air yang lebih rendah dibandingkan dengan penambahan pengawet alami daun jambu biji.

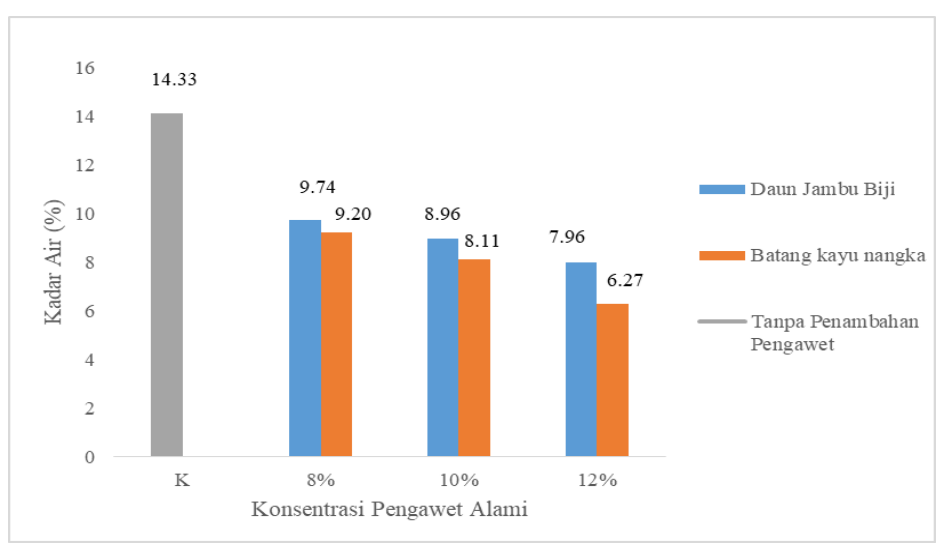

Gambar 4.Kadar Air

Kadar air sangat penting untuk mengetahui mutu suatu produk pangan. Air yang terdapat dalam bentuk bebas pada bahan pangan dapat membantu proses terjadinya kerusakan bahan pangan. Kadar air dalam suatu bahan berperan dalam reaksi kimia, perubahan enzimatis ataupun pertumbuhan mikroorganisme. Hal tersebut terjadi umumnya pada kadar air tinggi dan akan mempengaruhi faktor lingkungan seperti $\mathrm{pH}$ dan suhu. Kadar air berpengaruh pada kualitas dan stabilitas produk secara menyeluruh (Zohratun. 2017).

Hasil analisis sidik ragam menunjukkan bahwa $\mathrm{F}$ hitung > F tabel pada konsentrasi penambahan pengawet alami dan jenis pengawet alami berpengaruh sangat nyata terhadap tingkat kadar air yang dihasilkan sehingga dilakukan uji duncan, dari hasil analisis uji duncan menunjukkan perlakuan terbaik untuk konsentrasi pengawet alami yaitu 12 $\%$, dan jenis pengawet alami yaitu batang 
kayu nangka lebih baik dibandingkan dengan daun jambu biji. hal ini sejalan dengan kandungan mikroba yaang lebih rendah pada konsentrasi $12 \%$ dan penambahan batang kayu nangka, karena jumlah mikroba yang rendah sehingga fermentasi terhambat karena kita ketahui bahwa pada proses fementasi tersebut dapat menghasilkan gula reduksi yang terdiri dari glukosa dan fruktosa sesuai dengan pernyataan Christina et al (2017) bahwa adanya komposisi gula invert (glukosa dan fruktosa) menyebabkan gula lebih higroskopis dan menurut Hartomo \& Wijiatmoko (2006) bahwa fruktosa bersifat higroskopis, larutan kuat fruktosa tetap lembab dan fruktosa mudah sekali larut dalam air, kadar air yang tinggi ditunjukkan dengan tekstur produk yang basah, gula bersifat higroskopis, yakni mudah menyerap air hal ini akan menyebabkan daya simpan produk yang rendah, sehingga dapat meneyebabkan terjadinya penggumpalan (cumpling) dan berpengaruh pada kualitas fisik produk
(Zohratun. 2017), namun kadar air yang dihasilkan dari kedua faktor konsentrasi dan jenis pengawet alami yakni kadar air yang memenuhi standar SNI yaitu dibawah $10 \%$ (Badan Standarisasi Nasional. 1995).

Tekstur gula aren yang dihasilkan dengan penambahan pengawet alami memiliki tekstur yang lebih keras dibandingkan dengan tekstur gula aren tanpa penambahan gula aren, karena tekstur gula dipengaruhi oleh kadar air hal ini sesuai dengan pernyatan Maya et al (2014) bahwa kadar air yang rendah menghasilkan tekstur yang lebih keras.

\section{Kadar Gula Reduksi}

Pada Gambar 4.5 terlihat bahwa semakin tinggi konsentrasi maka semakin rendah kadar gula reduksi yang dihasilkan, dan untuk jenis pengawet alami daun jambu biji menghasilkan kadar gula reduksi yang lebih tinggi dibandingkan dengan kadar gula reduski yang dihasilkan dengan penamabahn pengawet alami batang kayu nangka.

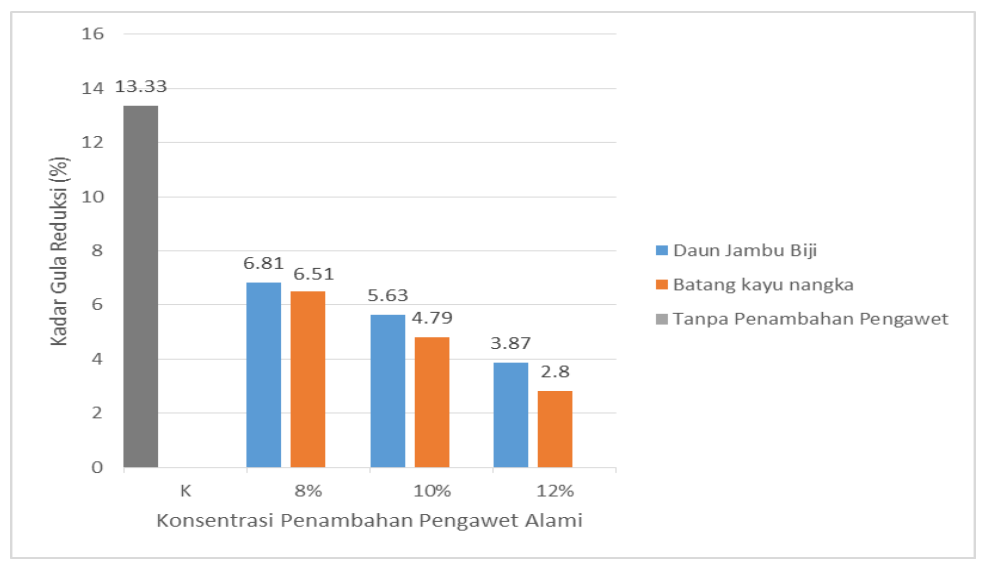

Gambar 5.Kadar gula reduksi

Gula pereduksi adalah gula yang memiliki gugus aldehid bebas pada struktur kimianya. Kandungan gula pereduksi berperan dalam proses pencoklatan nira. Gula pereduksi juga mempengaruhi tingkat kemanisan, karena glukosa dan fruktosa mempunyai tingkat kemanisan yang rendah (Zohratun, 2017).

Hasil analisis sidik ragam menunjukkan bahwa nilai $\mathrm{F}$ hitung > F tabel pada konsentrasi pengawet alami berpengaruh nyata terhadap tingkat gula reduksi yang 
dihasilkan, oleh karena itu dilakukan uji duncan, Hasil analisis uji duncan menunjukkan bahwa perlakuan terbaik yaitu dengan konsentrasi $12 \%$. Semakin tinggi konsentrasi maka semakin terhambat pula proses fermentasi sehingga hal ini sejalan dengan derajat $\mathrm{pH}$ dan penurunan jumlah mikroba pada konsentrasi rendah yang menyebabkan laju fermentasi terhambat sehingga gula reduski yang dihasilkan juga rendah hal ini sesuai dengn pernyataan (Naufalin et al) 2013 bahwa semakin meningkatnya konsentrasi penggunaan bahan pengawet alami mengakibatkan aktivitas mikroba menurun dan penurunan $\mathrm{pH}$ nira dihambat, sehingga gula pada nira tidak dihidrolisis menjadi gula reduksi

Jenis pengawet alami untuk kadar gula reduksi yakni batang kayu nangka lebih baik diabandingkan dengan daun jambu biji, hal ini sejalan dengan jumlah mikroba yang dihasilkan, jumlah mikroba yang ada pada nira aren pada perlakuan batang kayu nangka lebih rendah dibanding dengan daun jambu biji, hal ini menyebabkan kurangnya gula reduksi yang merupakan hasil dari fermentasi hal ini sesuai dengan pendapat Eka, et al (2008), salah satu tanda kerusakan nira yaitu terjadinya penurunan nilai $\mathrm{pH}$ yang disebabkan adanya perombakan gula menjadi asam organik oleh mikroba seperti khamir (Saccharomyces sp.) serta bakteri (Acetobacter sp.). Selain itu, kontaminasi yang oleh mikroba dapat menyebabkan penurunan kadar sukrosa dan peningkatan kadar gula reduksi pada nira, hal ini sesuai dengan pernyataan Dwi \& Wahyono (2014) bahwa nira sangat mudah mengalami kerusakan, salah satu kerusakannya ialah kadar sukrosa pada nira terinversi menjadi gula pereduksi yang terdiri dari glukosa dan fruktosa, inversi sukrosa salah satunya disebabkan oleh aktivitas mikroorganisme.

Kadar gula pereduksi pada gula merah juga berkaitan dengan mutu gula merah, karena kadar gula reduksi yang tinggi pada gula merah menunjukkan kualitas yang kurang baik karena kurang awet pada saat disimpan, hal ini sesuai dengan penelitian Fitriyanti et al (2014) bahwa kadar gula reduksi yang tinggi menyebabkan gula menjadi lebih higroskopis (mudah menyerap air) sehingga mudah meleleh pada penyimpanan, selain itu gula merah juga mempengaruhi mutu gula seperti pada penelitian Naufalin, et al (2013) bahwa semakin rendah nilai gula reduksi, semakin meningkat mutu gula yang dihasilkan, karena mempengaruhi kekerasan, warna dan rasa gula merah.

Gula reduksi menurut SNI-01-73431995 yaitu sebesar 10\% Badan Standarisasi Nasional (1995). Pada semua perlakuan menunjukkan kadar gula reduksinya rendah yaitu di bawah batas maksimal standar SNI $10 \%$ bb. Semakin rendah nilai gula reduksi, semakin meningkat mutu gula yang akan mempengaruhi tingkat kekerasan, warna dan rasa gula kelapa (Naufalin et al. 2013).

Warna yang dihasilkan dipengaruhi oleh kadar gula reduksi yang dihasilkan semakin tinggi kadar gula reduksi maka gula merah yang dihasilkan menjadi lebih kecoklatan berbeda dengan warna yang dihasilkan oleh gula merah dengan kadar gula reduksi yang rendah memiliki warna yang lebih coklat kemerahan hal ini didukung oleh pendapat Zohratun (2017) bahwa kandungan gula pereduksi berperan dalam proses pencoklatan nira, gula invert 
JPTP Jurnal Pendidikan Teknologi Pertania

banyak memgandung gula pereduksi akan lebih mengalami proses pencoklatan sehingga warnanya lebih coklat. Gula pereduksi juga mempengaruhi tingkat kemanisan karena glukosa dan fruktosa mempunyai tingkat kemanisan yang rendah. Selain itu, warna pada gula merah

\section{Simpulan}

Berdasarkan hasil penelitian yang telah dilakukan, maka dapat disimpulkan bahwa Penambahan konsentrasi dan jenis pengawet alami dengan konsentasi dan jenis yang berbeda berpengaruh terhadap fermentasi nira aren ditunjukkan dengan nilai $\mathrm{pH}$, Total Saccharomyces cerevisiae, dan Total Acetobacter acetii yang dihasilkan. Perlakuan terbaik diperoleh pada konsentrasi penambahan pengawet alami pada daun jambi biji ialah $12 \%$ dan untuk jenis pengawet alami yang terbaik yaitu batang kayu nangka dan penambahan pengawet alami dengan konsentasi dan jenis yang berbeda berpengaruh terhadap kualitas gula aren ditunjukkan dengan kadar gula reduksi dan kadar air menunjukkan adanya pengaruh nyata. Perlakuan terbaik diperoleh pada konsentrasi penambahan pengawet alami pada daun jambi biji ialah $12 \%$ dan untuk jenis pengawet alami yang terbaik yaitu batang kayu nangka.

\section{Daftar Pustaka}

Afifi, E \& Erlin, E. 2017. Uji Anti Bakteri Ekstrak Daun Jambu Biji (Psidium guajava L.) Terhadap Zona Hambat Bakateri Jerawat Propinobacterium ares Secara Alami. Jurnal Kesehatan
Volume 5, 2019

juga disebabkan karena pemesakan, hal ini sesuai dengan pernyatan bahwa pemanasan terlalu lama akan mengakibatkan karamelisasi dan perubahan warna gula (Irmayuni et al, 2018).

Bakti Yunus Husada. 17 (2): $321-330$.

Badan Pusat Statistik (BPS). 2018. Ratarata Konsumsi Perkapita Beberapa Macam Bahan Makanan Penting. Jakarta: Badan Pusat Statistik.

Badan Standarisasi Nasional (BSN). 1995. Standar SNI Gula Merah. Jakarta: Badan Standarisasi Nasional.

Candra, D.R. 2009. Uji Aktivitas Antijamur Ekstrak Buih Pare Belut Trichosanthes augina L). Skripsi. Surakarta: Universitas Sebelas Maret

Chomnawang, M. T., Surasmo, S., Nukokam \& Gritparman, 2005). Antibacterial Effect of Thai Menchal Planst Against Acne- Inducing Bacteria. Journal Eupharmacol 10: 303 -330 .

Christina, T. E., Thomas, E.P \& Setiawati, B. 2017. Pengaruh Penambahan Proporsi Gula Pasir dan Gula Aren pada Karakteristik Creamcheese Cake Setelah Satu Minggu Penyimpanan Beku. Jurnal Teknologi Pangan dan Gizi. 16(2) : 88 -95. 
Dwi, M.E \& Wahyono, H.S, 2014. Pengaruh pH Nira Tebu (Saccharum Officinarum) dan Konsentrasi Penambahan Kapur Terhadap Kualitas Gula Merah. Jurnal Pangan dan Agroindustri. 2(3): 54-64.

Eka, P., Agustinus \& Halim, A. 2008. Pembuatan Bioethanol dan Nira Siwalan Secara Fermentasi Fermentasi Fase Cair Menggunakan Fermipan. Skripsi. Semarang: Universitas Diponegoro.

Ernasari, Patang \& Kadirman. 2018. Pemanfaatan Sari Tebu (Saccharum officinarum) dan Lama Fermentasi Kacang Tunggak Terhadap kualitas Kecap Manis Kacang Tunggak (Vigna unicallita). Jurnal Pendidikan Teknologi Pertanian. 4 (2018): 88-100.

Ernawati \& Kumalasari. 2015. Kandungan Senyawa Kimia dan aktivitas Antibakteri Ekstrak Kuliat Buah alpukat terhdapa bakteri Vibrio auginoliticus. Jurnal kajian Veteriner. 16 (2): 203 211.

Erna, M. K. 2013. Efek Fermentasi dengan Saccharomyces cerevisiae terhadap karakteristik Biokimia Tapioka. Agritech, 33(3): $281-287$.

Ersam, T. 2001. Senyawa Kimia Mikromolekul Beberapa Tumbuhan Artocarpus Hutan Tropics Sumatra Barat.
Disertasi. Bandung: Institut Teknologi Bandung.

Fitriyani, J., Djangi., Muhammad \& Alimin. 2014. Pengaruh Penambahan Daun Manggis Hutan (Garcinia Hombroniana Pierre) Terhadap Umur Simpan Nira Aren (Arenga Pinnata Merr). Jurnal Chemichal. 15 (1): 82 93.

Hartomo, AJ \& Wijatmoko, MC. 2006. Emulsi dan Pangan Instan Ber- Lesitin. Penerbit Andi: Yogyakarta.

Indriani, S. 2006. Aktivitas Antioksidan Daun Jambu Biji (Online). http://repository.ipb.ac.id, diakses tenggal 16 Mei 2018.

Irmayuni, B., Nurmilah., Andi, S. 2018. Efektivitas Air Nira Lontar (Borossusflabellifer) Sebagai Bahan Pengembang Adonan Kue Apem. Jurnal Pendidikan Teknologi Pertanian. 2(2018): 170-183.

Jayadi, F., Andi, S \& Muhammad, R. 2018. Pemanfaatan Tepung Daun Mangrove (Achantus ilicifolius) Sabagai Pengawet Alami Bakso Ayam. Jurnal Pendidikan Teknologi Pertanian. 4(2018): 1-13

Lubis, Ricky Fauzi., Rona J, N \& Mimi. N. 2013. Pengaruh Penambahan Konsentrasi Bahan Pengawet Alami Pada Nira Aren Selama 
JPTP Jurnal Pendidikan Teknologi Pertania

Volume 5, 2019

Penyimpanan Terhadap Mutu

Gula Aren Cair. Jurnal

Rekayasa Pangan dan

Pertanian. I (4): 76- 84.

Pratiwi. R R.,Sri, L \& Heri. FT. 2014. Uji Aktivitas Anti Bakteri Ekstrak Etanol Daun Mangga Bacang (Mangifera foetdei L.) Terhadap Staphylococcus aerues Secara In Vitro. (online). (www.neliti.com, diakses 10 Oktober 2018).

Rahmawati R., Defiana, M. T \& Suriani, M. R. 2009. Pengaruh Suhu dan Lama Penyimpanan Terhadap Landungan Vitamin C Cabai Rawit Putih (Capsium frustescens). Jurnal Biology. 8(2): 36-40.

Marsigit, W. 2005. Penggunaan Bahan Tambahan pada Nira dan Mutu Gula Aren yang Dihasilkan Dibeberapa Sentra Produski di Bengkulu. Jurnal Nasional Indonesia. 9(1): 4298.

Maryati, J., M \& Karmila. 2008. Pemanfaatan Daun Jambu Biji (Psidium guajava) Sebagai Alternatif Pengawetan Telur Ayam Ras (Online). (http://isjd.pdii.lipi.go.id.pdf, diakses 16 Mei 2018).

Maya, D. M., Yulianingisih, R., Rosalia.

S. D., Sugiarto. Y \& Wahyu D. I. 2014. Pengaruh Penambahan Natrium Metabisulfat dan Suhu Pemasakan Dengan Menggunakan Teknologi
Teknologi Vakum Terhadap Kualitas Gula Merah Tebu. Agritech. 34(4): 365-373.

Muchtadi, D. 2010. Kedelai: Komponen Bioaktif Untuk Kesehatan. Bandung: Alfabeta.

Naufalin, R., Tri ,Y \& Anna, S. 2013. Pengaruh dan Konsetrasi Pengawet Alalmi Terhadap Mutu Gula Kelapa Yang dihasilkan. Jurnal Teknologi Pertanian. 14 (3) : 165 - 174.

Setya, R.P., Tjiptasurasa dan Retno, W. 2011. Aktivitas Antibakteri Ekstrak Etanol Kayu Nangka (Arthocarpus heterophyla LMK) Terhadap Bacillus Subtilsa dan Eschhrecia coli. Parmach. 8 (3): 1993 -359).

Sirotua, P., Santosa, G \& Herla, R. 2015. Pengaruh Penambahan Berbagai Pengawet Alami dan Konsentrasinya Terhdapa Mutu Nira Aren. Jurnal rekayasa pangan dan Pertanian. 3(4): 458-463.

Sukainah, A., Eva, J \& Reski, P.P. 2018. Identification and isolation of fungi indigenus on spontaneous fermentation corn flour Bisi 18, Eco. Env. \& Cons. 24 (1): 132-139.

Sukaianah, A., Eva, J \& Reski, P.P. 2017. Isolasi dan Identifikasi Bakteri Indigenus pada Tepung Jagung Bisi 16 selama Proses Fermentasi. Prosiding Seminar PATPI 2017. PATPI Cabang Lampung. Bandar 
JPTP Jurnal Pendidikan Teknologi Pertania

Volume 5, 2019

Lampung. 10-12 November 2017.

Universitas

Padjajaran.

Jatinagor.

Sukainah, A., Reski, P. P \& Husnul, H. 2018. The Change in Aspergillus sp. Population During The Process of Controlled Corn Flour Fermentatoin and The Rheogical Propertis of Corn Flour Produces, (Online). Volume 201. (http:download.atlantis.press.c om, diakses 31 Januari 2019).

Sumanti, D., Tjahjadi, C., Betty, D.S., Cucu, S. A., \& Abdul, R. 2004. Efek Bahan Pengawet Alami Terhadap Pertumbuhan Mikroorrganisme Kontaminan Nira Aren. Laporan Penelitian Fakultas

Pertanian.

Widowati, P. 2017. Sitoksisitas Ekstrak Metanol Daun Sukun (Artocarpus atillis), Nangka (Artocarpus heterophylus) dan kluwih (Artocarpus camansi) Terhadap Sel Kanker Payudara. Skripsi. Surakarta: Universitas Surakarta.

Zahrotun, S, T. 2017. Pengaruh Penambahan Gula Merah Cair dan Nira Terhadap Karakteristik Gula Semut (Palm Sugar). Skripsi. Bandung: Universitas Pasundan. 